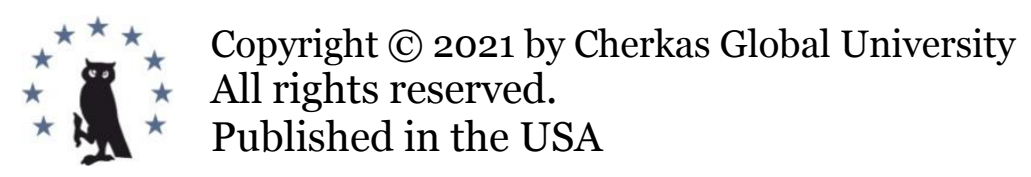

European Journal of Contemporary Education

E-ISSN 2305-6746

2021. 10(4): 854-867

DOI: $10.13187 /$ ejced.2021.4.854

https://ejce.cherkasgu.press

\begin{abstract}
IMPORTANT NOTICE! Any copying, reproduction, distribution, republication (in whole or in part), or otherwise commercial use of this work in violation of the author(s) rights will be prosecuted in accordance with international law. The use of hyperlinks to the work will not be considered copyright infringement.
\end{abstract}

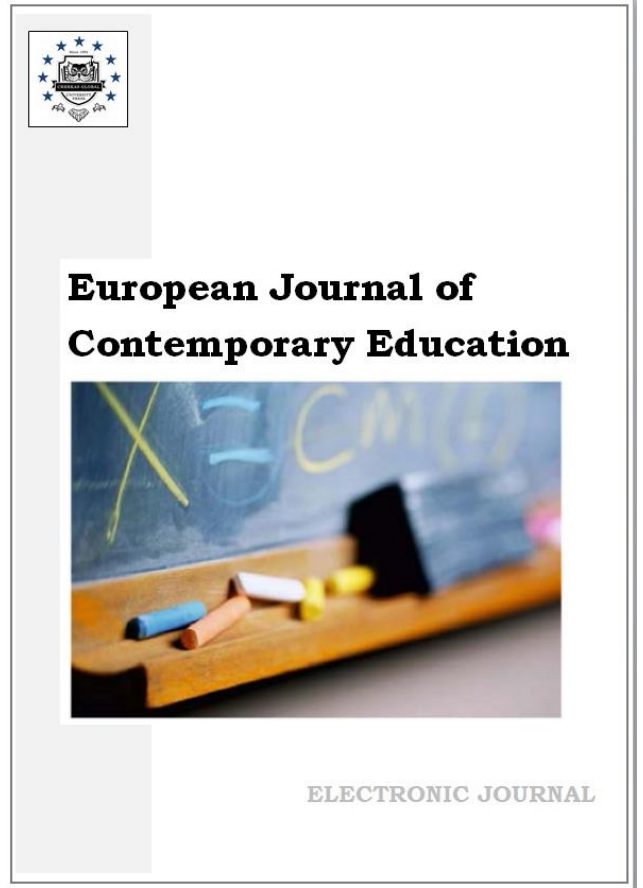

\title{
Methodological Support for Systemic Change in Russian Comprehensive School: Problems, Models and Development Mechanisms
}

\author{
Tatyana P. Afanasyeva a, Valentina V. Krylova ${ }^{\text {b }, ~ I r i n a ~ M . ~ L o g v i n o v a ~ a ~, ~ Y u r i ~ S . ~ T y u n n i k o v ~ a ~ b ~, ~ * ~}$

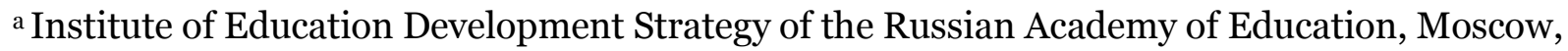 \\ Russian Federation \\ b Sochi State University, Sochi, Russian Federation
}

\begin{abstract}
Improving the quality of school education is one of the most important directions in the development of the education system of the Russian Federation, requiring interrelated changes in all components of the pedagogical systems of schools: goals, content of educational programs, educational technologies, forms of control of educational activities, methods of assessing its results. The implementation of systemic innovations by schools is faced with a lack of readiness for innovative activities among the majority of teachers. Being the subjects of educational activity, teachers have not yet become the subjects of its development determining the content and form of the processes of school development. Therefore, a key factor in the success of systemic changes in schools is their timely and high-quality methodological support aimed at creating a set of conditions that ensure the inclusion of teachers in innovative activity as its subjects, and increasing their readiness for systemic changes within the framework of this activity. The authors present a structural-functional model of methodological support for the implementation of systemic innovations by schools. The model integrates the activities of methodological structures of all levels of management of the general education system and public and professional associations of educational workers to solve the problems of methodological support for the systemic development of schools. These tasks include identifying support needs, finding and creating the necessary tools and methods for this, ensuring access to them, and supporting their use. A systemic nature of methodological support is ensured through the development and implementation of a program for the consistent solution of all its tasks in the areas identified in the model (organizational and
\end{abstract}

\footnotetext{
* Corresponding author

E-mail addresses: tunn@yandex.ru (Yu.S. Tyunnikov), inido-atp@mail.ru (T.P. Afanasyeva), valensiyaletter@mail.ru (V.V. Krylova), Logvinova@instrao.ru (I.M. Logvinova)
} 
managerial, scientific and methodological, informational, educational, expert and advisory) for each stage of system innovation. An assessment of the changes that have taken place in regional systems of methodological work in recent years has revealed their innovative potential, which can be used in the modernization of methodological activities on the basis of a structural-functional model of methodological support for the systemic development of schools as a normative one.

Keywords: innovative activity, methodological activity, methodological support, model of methodological support, general education, system innovation.

\section{Introduction}

The Russian system of general education needs serious qualitative changes. And although changes are taking place in it, their intensity and effectiveness do not meet the real needs of society and the state. One of the main reasons is the imperfection of educational development mechanisms that do not provide the necessary improvement of its quality and international competitiveness.

The condition of the general education system was assessed as critical back in the early 9os of the last century. The situation began to change for the better only from the turn of the new century. However, despite the fact that many important documents aimed at the development of education were adopted at the government level, real changes for the better either did not occur or were insignificant, primarily due to the low efficiency of the development mechanisms.

In 2006, the report of the working group at the State Council meeting "On the development of education in the Russian Federation" noted that the implementation of the tasks of modernization of education in 2001-2005 gave it the opportunity to reach the stable level of functioning, but at the same time the majority of the planned measures were not implemented. The reasons for this were "ineffective methods of implementing changes", "lack of interest in the modernization of education on the part of various social forces", "insufficient support for transformations on the part of regional authorities" (Doklad ..., 2006).

The Concept of the Federal Target Program for the Development of Education for 2006-2010 noted "the lack of mechanisms in the national education system to identify, support and disseminate the best examples of innovative educational activities", and in the Concept of modernization of Russian education until 2010, the creation of a mechanism for sustainable development of the education system was identified as the main goal.

Currently, "neither mechanisms for the sustainable development of the education system, nor even such a project have been created. They will have to be created if we really want national education to develop in accordance with the requirements of the XXI century and be competitive" (Lazarev, 2015). Ensuring the "global competitiveness of Russian education, the entry of the Russian Federation into the top 10 countries of the world in terms of the quality of general education" are declared as national goals of education development (O natsional'nykh..., 2020). However, to achieve it, radical changes are needed in the pedagogical systems of most Russian schools.

\section{Methodology}

In our study, the development of the model of methodological support for schools implementing systemic innovations was based on the methodology of system-activity approach to the study and transformation of reality; system analysis as a methodology of systemic problem solving based on the concept of targeted systems; methodology of pedagogical research; the concept of organizational development. The theoretical basis of the study included: the psychological theory of activity, the key provisions of the theory of enhancing pedagogical systems.

In developing the model there has been done the analysis of methodological standards and a wide range of publications on the subject. Most authors of scientific research at the end of the last and beginning of this century associated methodical work with improving the qualifications and professional skills of teachers. In modern research there is a conceptual rethinking of methodical activity "with changes in understanding of its essence, the main purpose, updating of the tasks it solves, changes in the corresponding requirements to its organization and implementation" (Zagrivnaya, 2006).

The main differences in methodological support for schools implementing systemic innovations as one of the components of methodological activity include: use of administrative mechanisms and methods of work by its subjects as auxiliary assistance; positive attitude and voluntary acceptance of support from schools and teachers; prevalence of dialogue, increased importance of feedback; 
replacement of vertical, hierarchical links and relations by horizontal and network ones (Moiseev et al., 2013). The size, content, forms and methods of support in each case are focused on stimulation of innovative activity of both individual teachers and the teaching staff as a whole.

The mechanism of support influences systemic development of schools and includes influence on educational performance of students but not directly, rather indirectly - through changes in educational and other processes of school and living conditions. However, changes of conditions, environment, processes and results of educational activities are possible only through influence on the existing communities of teachers-subjects of educational and innovative activity, on their goal-setting, motivation, ways of their activity.

To determine the conformity of the current state, identify current problems and opportunities for the development of the system of methodological activities in general education on the basis of the model developed by us to support the systemic development of schools, the method of analysis of expert assessments with the involvement of representatives of regional, municipal and institutional (school) methodological structures was used. The selection of experts participating in the study was carried out by the regions independently.

The collection of initial information was carried out according to the questionnaire methodology, processing was carried out by means of the SPSS statistical software package. The analysis of the obtained data was carried out using descriptive statistics, correlation analysis and other types of statistical analytics.

\section{Discussion}

The pedagogical system is understood by us "as a seamless unity consisting of a set of components (educational programs, technologies, students, teaching staff, didactic and logistical means, etc.) connected in such a way that a purposeful educational process takes place in it, and at the same time changes are made in its structure and components (an innovative process is carried out), as a result of which it acquires the ability to achieve higher educational results than before" (Lazarev, 2010). The analysis of innovations - targeted changes in the pedagogical systems of schools - shows that most of them carry out only fragmentary, local improvements in their activities, and systemic innovations involving the restructuring of the entire educational system under the idea of improving the quality of education can be implemented only by a small part of innovative schools with high sensitivity to needs and high susceptibility to the possibilities of their development, as well as with high readiness of teachers for innovation (Lazarev, 2010).

By "readiness for innovative activity" we mean "a set of qualities of a teacher that determine his/her focus on the development of their own pedagogical activity and the activities of the entire school" (Lazarev, 2010). Innovative activity of teachers under systemic changes in schools has a hierarchical structure. It is implemented at 3 levels and is aimed: at the individual level - at the development of their own pedagogical activity; at the group level - at the development of pedagogical activity of school subsystems; at the collective level - at the development of the activities of the whole school as a whole. A teacher can be involved in innovation processes at these levels to varying degrees, but as a subject of collective activity, he $\backslash$ she is fully implemented at the level of the educational system as a whole, being involved in solving the problems of improving the quality of education at all three levels of innovation.

Acting as the subject of the school's innovation activity, a teacher, together with other teachers and the administration, implements the functions of managing this activity: determines the content and form of the school's development processes (determines the overall strategy of behavior; identifies problems; looks for ways to solve them; sets goals (projects the image of the desired future); plans development; organizes the implementation of plans; controls and regulates the processes of change). As a result, a common understanding of the actual problems of the school, the goals of innovation activity, ways to achieve them is formed, responsibility for the implementation of various areas of joint work is distributed and accepted (Tyunnikov, 2017).

The subject of activity is characterized by the fact that his/her own motive for this activity coincides with its socially significant (objective) motive, by the fact that he/she assumes responsibility for the implementation of this activity, plays active role in its implementation, and also demonstrates the (cultural) ways of its implementation, developed in a given society (Lazarev, Razuvayeva, 2009). Consequently, the teacher as a subject of innovative activity is distinguished by: 
- the formation of his/her need to change the educational system of his/her school in order to achieve higher educational results;

- the ability to consciously, purposefully transform pedagogical reality, to be active in its implementation;

- assuming responsibility for solving the tasks of innovative activity; possession of special means and technologies for solving these tasks;

- the ability to independently organize, control and make adjustments to the work of teachers to introduce innovations without participation of the administration.

Within the framework of the scientific school of developing pedagogical systems, the authors have developed a model of the teacher's readiness to be a subject of innovative activity, which sets criteria and indicators of the level of his/her readiness to manage the school development and revealing the factors determining this level (Figure 1) (Afanasyeva, 2016; Afanasyeva et al., 2016). The groups of teachers with high, medium and low levels of readiness for innovative activity at school are identified by statistically significant difference in the formation of its motivational, cognitive, technological and organizational components. The methodology for assessing a teacher's readiness for innovative activity allows determining factors that reduce its level, developing individual trajectories for increasing his/her innovative competence, as well as ensuring productive inclusion in the development of a school development program (Afanasyeva et al., 2016).

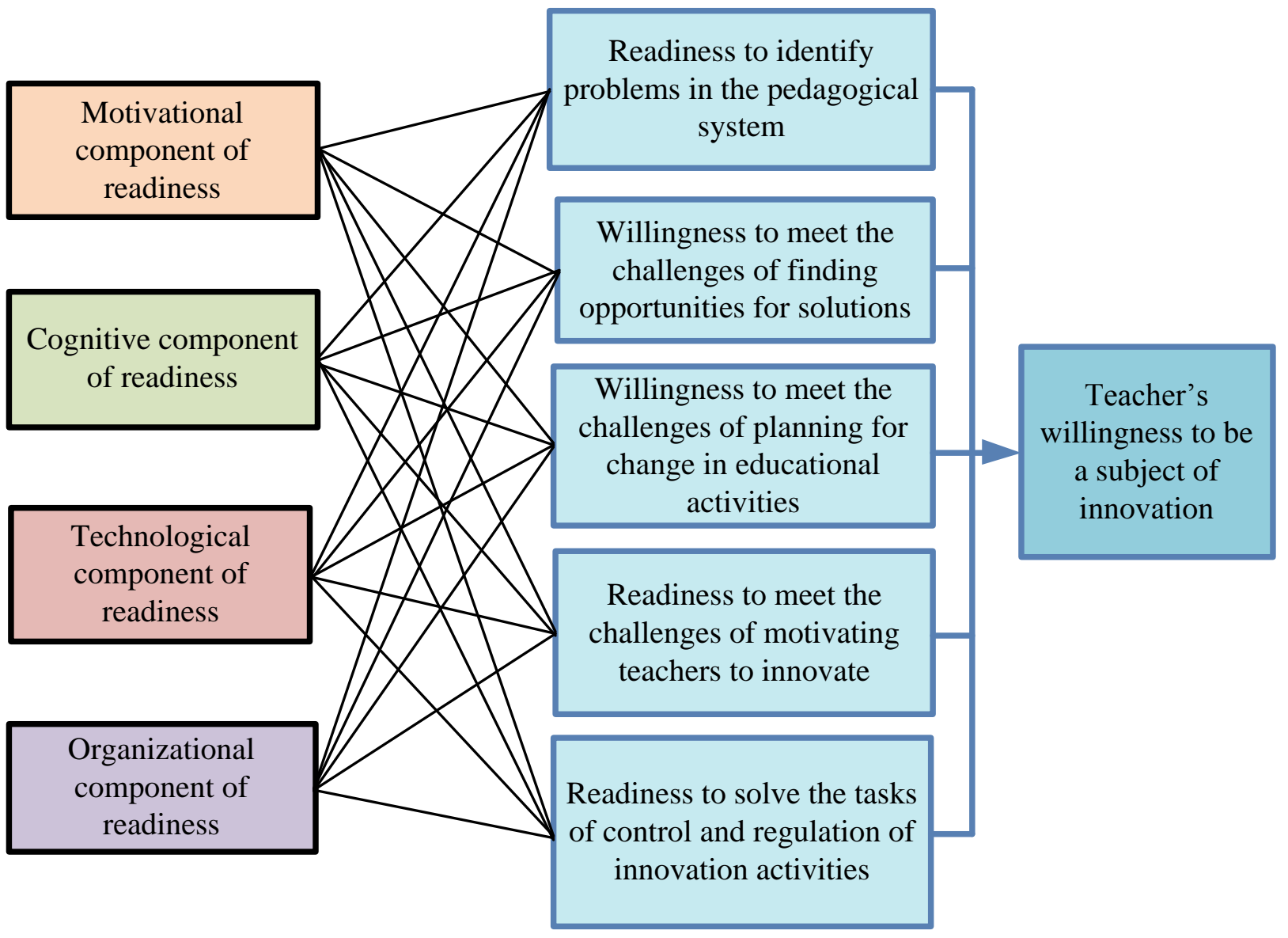

Fig. 1. Structural and functional model of teacher's readiness to manage the development of their school

The willingness of teachers to innovate at school is also evident in how they relate to the changes currently taking place in general education.

We conducted the survey of teachers 4380 teachers from 82 regions of the Russian Federation in relation to the changes taking place in the general education system, to ensure its quality and international competitiveness, according to Figure 2 there were 4 groups: 
- the largest group - about half of the respondents are quite satisfied with the development of the general education system, considering the intensity of the change in the system as "adequate";

- the second largest group ( $28.6 \%$ of the total) believe that the speed of change is "too high";

- only $16.8 \%$ of respondents are confident that the rate of change is "somewhat lower than necessary";

- there is a very small group (4.2\% of teachers) who believe that the intensity of changes is "significantly lower than necessary."

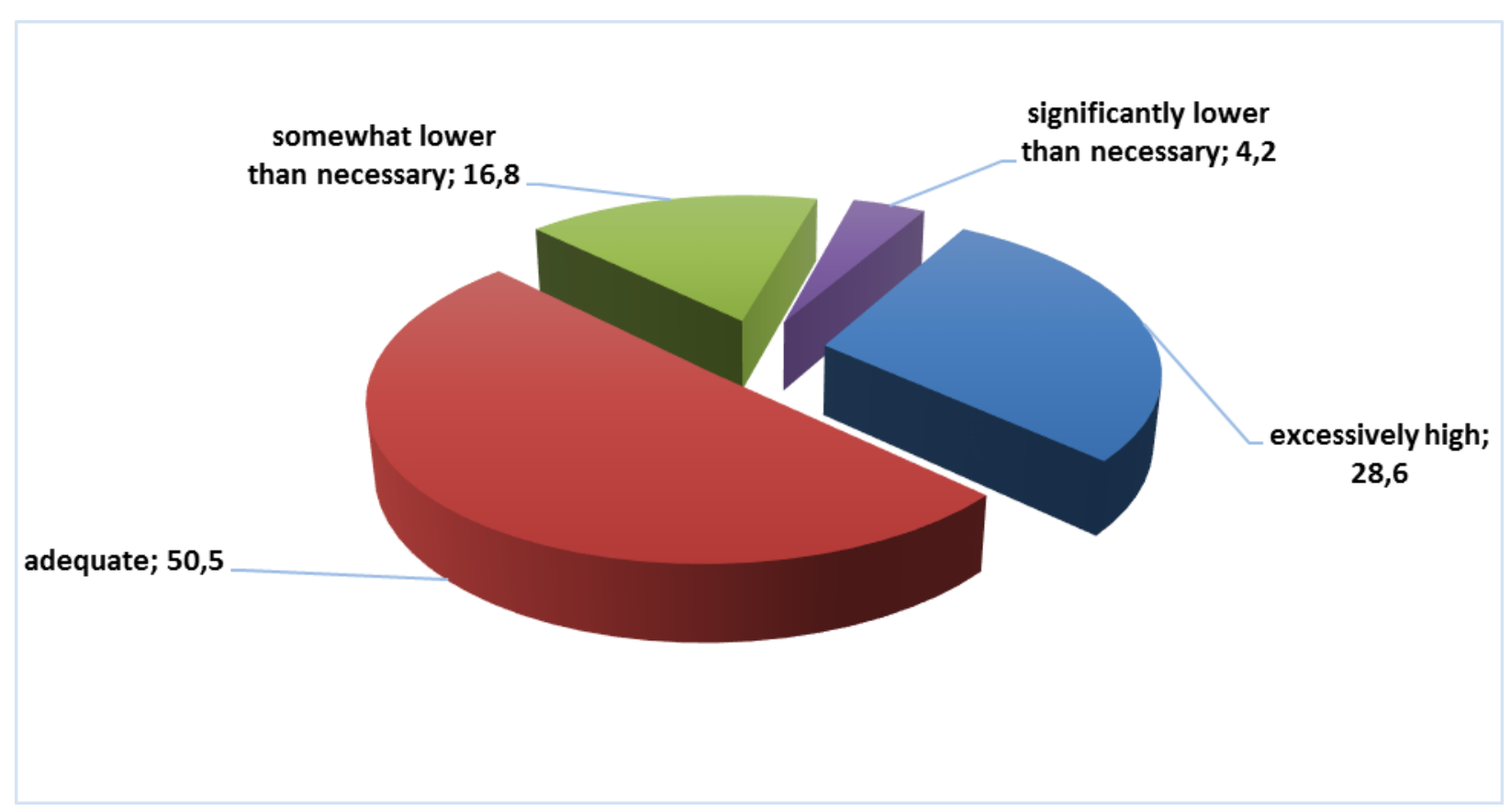

Fig. 2. Russian school teachers' assessment of the intensity of change of general education to ensure its quality and international competitiveness (in \%)

Thus, only a fifth of the teachers surveyed consider the intensity of change in general education to be less than necessary. Some of them can independently engage in innovative activities in order to accelerate changes and improve the quality of education in their schools. In this regard it is reasonable to ask: "And how do the rest of the teachers react to the changes?

Analysis shows that the following situations are frequent when teachers:

- resist the introduction of the proposed innovations, not wanting to change anything in themselves, in their system of values and beliefs, in their activities, to master new methods and technologies;

- act as if doing innovative activity, trying to present themselves as teachers-innovators and creative people, actually changing little in their work;

- blindly copy the work of their colleagues and follow instructions from the school administration, they get the results of the innovation that does not correspond to their expectations;

- reproduce an innovative activity and quickly give up on the further use of innovation after having introduced it, because of a wrong understanding of its role

- do not bring to fruition their implementation of some innovation that has been "imposed from above" without understanding either the meaning, purpose of its implementation or its impact on the results of education (Lazarev et al., 2008).

As we see, innovative activity of teachers in most cases does not correspond to objective necessity. That is why the role of the organizer and the active motivator of innovative activity is often performed by the school administration, and teachers are only the executors of the goals and plans developed by it (Lazarev, Yeliseyeva, 2015). This is also confirmed by the results of the survey of teachers which showed that they, as a rule, participate in solving the problems of improving their 
own pedagogical activity, but rarely get involved in enhancing the school's activities (Lazarev, Razuvayeva, 2009).

Psychological research substantiates the connection between the teachers' readiness to be the subjects of school development by the existing opportunities to bring the teachers in the management of innovative activity and ramp up its effectiveness (Lazarev, Yeliseyeva, 2015). Therefore, the key factor of the success of systemic changes in schools is their timely and highquality methodological support - activities to create a set of conditions to ensure the inclusion of teachers in innovative activities as its subjects - and further increase their readiness for systemic innovations and implementation. Since teachers have different degrees of readiness for innovative activity and there are different conditions in schools, their needs for methodological support in the implementation of systemic innovations are different. Consequently, the problem of methodological support for teachers needs to be solved in a differentiated way by supporting teaching teams (hereinafter referred to as schools) that implement systemic innovations.

\section{Results}

The model of methodological support for schools implementing systemic innovations is a model of the system of joint activities of the subjects of support to create required conditions for the pedagogical staff of each school to modernize the educational system in order to improve the quality of education (Figure 3). The model integrates the activities of methodological services at all levels of the general education system (federal, regional, municipal and institutional) and public and professional associations of educators. As a result, a subject composition of methodological support is formed. Subjects of support differ from each other: by the degree of their motivation to support system innovations, by their potential to meet the needs of schools in necessary amount of support, by action plans to support system innovations, by the effectiveness of these plans.

The recipients of methodological support are school leaders, teaching teams, and individual teachers.

The main stages of building a system of methodological support for the systemic development of schools include:

- identification of interrelated areas of methodological support, ways of its implementation and results;

- the formation of a comprehensive subject of methodological support, capable of providing it at all stages of the development and implementation of systemic innovation;

- distribution of directions and tasks of methodological support between the levels of the system of methodological activity and methodological structures that make up the aggregate subject of methodological support;

- development of methodological support measures.

We consider the systemic development of the school from the standpoint of a system-active approach to the development of educational organizations, since such approach has been used to build a theoretically sound model of innovative activity that determines the sequence and content of actions to implement systemic innovations, their goals and expected results (Lazarev, 2010; Lazarev, 2015). The model has a high level of generality, expressed in the absence of a rigid connection with any one pedagogical system, as well as the ability to determine the requirements for the ways to perform all the main functions of innovation and the results of their implementation.

The development and implementation of a program of systemic changes in each school, according to the presented model, is carried out in five stages, each of which is characterized by a set of needs in objective support. The list of stages includes: formation of a working group to develop a project of systemic changes in the school's educational system; identification of necessary changes; development of a project for a modernized school educational system; development of a schedule for the modernization of the educational system; building an organizational mechanism for monitoring and regulating the process of modernization of the school's educational system and implementing planned changes. 


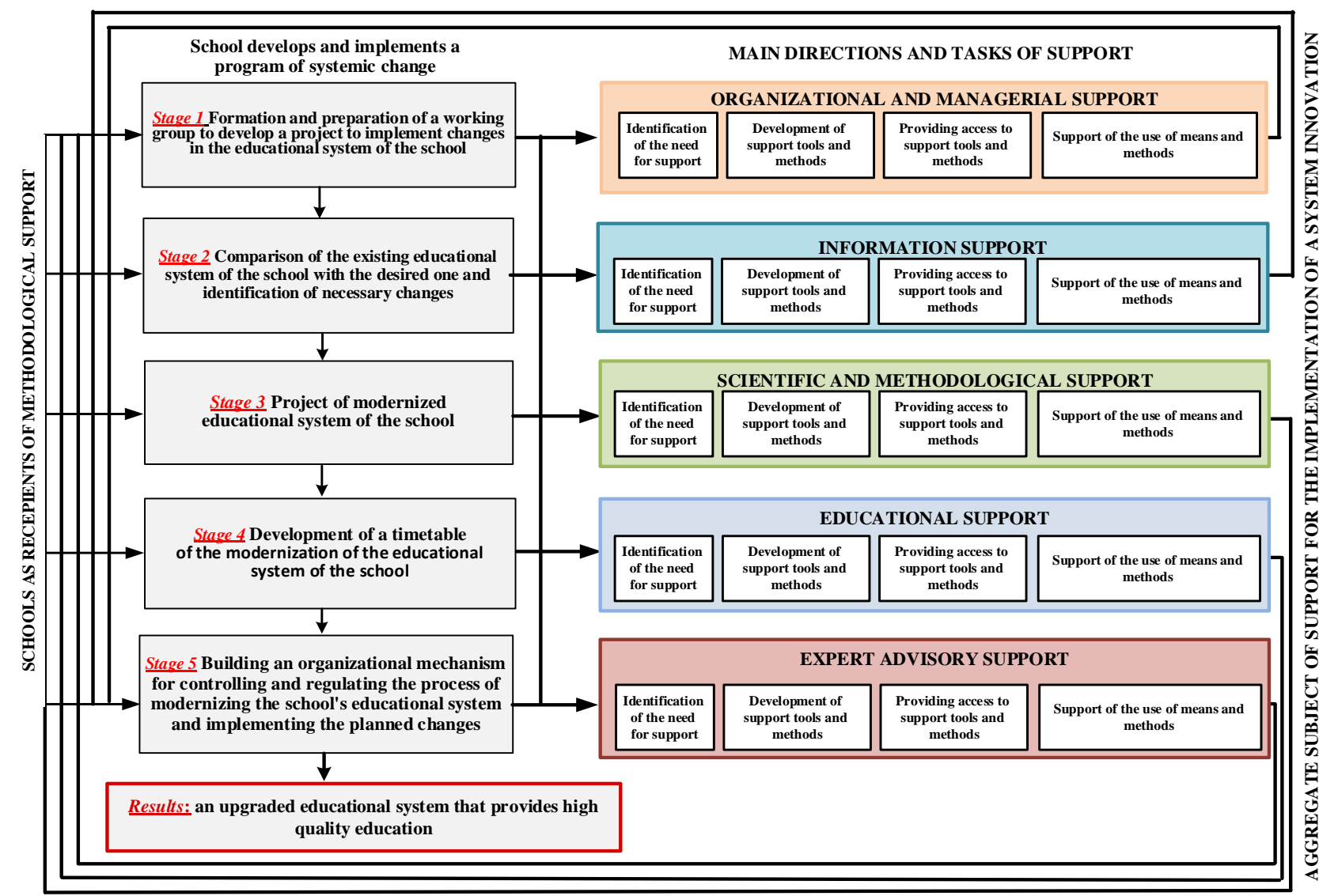

Fig. 3. Structural and functional model of methodological support for implementation of systemic innovation by the school

The model includes the following main areas of methodological support of schools:

- organizational and managerial support ensures temporary organizational structures in schools for the analysis of quality of education, developing projects to solve problems, and the distribution of rights, duties and responsibilities between the parties, the establishment of vertical and horizontal links between them, the establishment and effective functioning of the system of motivation of participants, changes, monitoring and adjusting their actions;

- scientific and methodological, aimed at supporting the development and introduction of new educational goals, content, forms, methods and technologies of teaching;

- informational, providing teachers with information necessary to solve the problems of systemic development of the school (about new pedagogical developments, about the quality, general shortcomings and causes of shortcomings of general education in Russia, region, district, school; about trends in the development of education, about new educational models, technologies, programs, best practices, etc.);

- educational providing, on the basis of the development and implementation of additional professional education programs, the formation of individual components of readiness for systemic innovations among school teachers;

- expert-advisory, based on the competence and experience of expert specialists, necessary where the situation cannot be unambiguously determined with the help of existing norms or there are many different norms, ideas, points of view.

Within each direction of methodological support, a set of invariant problems is solved:

- identification of the needs of schools for methodological support of this type;

- search and creation of the necessary means and methods of support (opportunities to meet them);

- providing schools with access to means and methods of support;

- support of the use of funds and methods of support by schools. 
The consistent solution of methodological support tasks at all stages of the school's systemic development in the selected areas of support as a result ensures the formation and implementation of a system of measures that ensure that the school more fully implements the required changes and uses development opportunities.

The most effective support for the introduction of systemic innovations by schools will be carried out on the basis of a program-oriented approach to manage the change. The main principles of program-target management are (Afanasyeva et al., 2016a):

- the principle of focus, the implementation of which implies the orientation of the support program as a whole and each of its parts to clearly defined goals and compliance of these goals with the actual needs of school development;

- the principle of concentration on priority areas, which requires identifying the most important problems and concentrating resources to solve them;

- the principle of consistency, requiring that the development of supported schools fit into the system of educational development as a whole;

- the principle of realism, which requires that all activities provided for in the program were provided with the resources necessary for their implementation, and that there were no external or internal constraints that would make their implementation impossible;

- the principle of target structuring of program management bodies, which means the organizational set-up of program management office should be in line with the target principle;

- the principle of integration, which establishes that the heads of relevant management bodies of the lower level should participate in planning at the higher level.

According to the program-target approach, efficient methodological support of system innovations requires development and implementation of programs, each of which includes: a value-meaning block (defines an image of the desired state of methodological support system, directions of its implementation); an instrumental and technological block (sets ways of movement from the actual state to the desired one); a content block (defines innovations, with which it is expected to solve existing problems fully or partially); resource block (includes all types of resources necessary and sufficient for the implementation of the program); organizational and management block (sets the organizational mechanism for the implementation of the program, including the means of monitoring the progress and results of work, algorithms for decisionmaking in case of deviations).

When carrying out system innovations methodological support on the basis of such a program will provide schools with the following: completeness of realization of objectively determined changes in educational activity; completeness of use of internal and external possibilities of development; efficiency of changes.

However, the question arises: is the existing system of methodological work capable of providing schools with adequate support necessary to significantly improve the quality of educational results?

The evaluation of the actual state of the system of methodological work in general education by 6,054 methodological staff at all levels (institutional, municipal and regional methodologists from 82 regions of the Russian Federation) is quite high, especially at the federal level (Figure 4). The respondents assessed the methodical work at the municipal level as being the lowest, which, according to one-third of the respondents, "to a lesser degree" and "mostly" does not meet modern requirements. As the analysis has shown, it is this level of the system of methodological work that has the lowest methodological potential. For example, in 48 regions out of 82 surveyed there are municipalities without methodological services. But in general, for most respondents the existing system of methodological work is quite up-to-date. 


\begin{tabular}{|c|c|c|c|c|c|}
\hline Federal level & 23,2 & \multicolumn{2}{|c|}{54,5} & 17,2 & 5 \\
\hline Regional level & 17 & \multicolumn{2}{|l|}{58} & 19,9 & 5,2 \\
\hline Municipal level & 16,5 & \multicolumn{2}{|l|}{50,7} & 24,2 & 8,7 \\
\hline \multirow{3}{*}{ Institutional level } & 17 & \multicolumn{2}{|l|}{53,5} & 21,5 & 8 \\
\hline & \multicolumn{3}{|c|}{$\begin{array}{l}\text { fully complies with up-to-date requirements } \\
\text { to a larger extent complies with up-to-date requirements } \\
\text { to a smaller extent complies with up-to-date requirements } \\
\text { mostly doesn't comply with up-to-date requirements }\end{array}$} & & \\
\hline & $\begin{array}{l}\text { fully complies } \\
\text { with up-to-date } \\
\text { requirements }\end{array}$ & $\begin{array}{l}\text { to a larger extent } \\
\text { complies with up-to- } \\
\text { date requirements }\end{array}$ & $\begin{array}{l}\text { to a smaller extent } \\
\text { complies with up- } \\
\text { to-date } \\
\text { requirements }\end{array}$ & \multicolumn{2}{|c|}{\begin{tabular}{|l|} 
mostly doesn't \\
comply with up-to- \\
date requirements
\end{tabular}} \\
\hline Federal level & 1406 & 3301 & 1044 & 303 & \\
\hline Regional level & 1027 & 3512 & 1203 & 312 & \\
\hline Municipal level & 998 & 3067 & 1463 & 526 & \\
\hline Institutional level & 1030 & 3237 & 1304 & 483 & \\
\hline
\end{tabular}

Fig. 4. Respondents' assessment of the system of methodological work at the federal, regional and institutional levels of management of the general education system (\%)

\begin{tabular}{|c|c|c|c|c|c|}
\hline \multicolumn{2}{|c|}{ Identification of the need for support } & 20,3 & 33,3 & 31,6 & 13,9 \\
\hline \multicolumn{2}{|l|}{ Development of support tools and methods } & 24,4 & 36,4 & 26 & 10,5 \\
\hline Providing access to support tools and methods & \multicolumn{2}{|c|}{19,5} & 34 & 32,1 & 10,5 \\
\hline \multicolumn{2}{|l|}{$\begin{array}{l}\text { Follow-up on the use of support tools and } \\
\text { methods }\end{array}$} & \multicolumn{2}{|c|}{32,3} & 34,7 & 13,2 \\
\hline \multicolumn{2}{|c|}{ a Federal level $\quad$ Regional level $\quad$ Municipal level } & \multicolumn{2}{|c|}{ Institutional level } & \multicolumn{2}{|c|}{ Task cannot be solved } \\
\hline & $\begin{array}{l}\text { Federal } \\
\text { level }\end{array}$ & $\begin{array}{l}\text { Regional } \\
\text { level }\end{array}$ & $\begin{array}{l}\text { Municipal } \\
\text { level }\end{array}$ & $\begin{array}{l}\text { Institutional } \\
\text { level }\end{array}$ & $\begin{array}{l}\text { Task } \\
\text { cannot be } \\
\text { solved }\end{array}$ \\
\hline Identification of the need for support & 2205 & 3394 & 3087 & 1753 & 407 \\
\hline Development of support tools and methods & 2544 & 3898 & 2708 & 1474 & 378 \\
\hline Providing access to support tools and methods & 2299 & 3691 & 3424 & 1844 & 360 \\
\hline $\begin{array}{l}\text { Follow-up on the use of support tools and } \\
\text { methods }\end{array}$ & 1764 & 3252 & 3362 & 2009 & 491 \\
\hline
\end{tabular}

Fig. 5. Distribution of respondents' opinions about the levels of the system of methodological work, at which the tasks of scientific and methodological support for professional development of teachers are solved (\%) 
Part of the methodological work at all levels of management of the education system is methodological support for the development of schools and teachers. 6,054 respondents were asked to determine at what level of government (federal, regional, municipal, institutional) the tasks we have identified are being solved. The survey results showed that all areas of methodological support differ little among themselves in the distribution of the contribution of different levels of the system of methodological work. As an example, we can consider scientific and methodological support for the professional development of teachers (Figure 5). At the same time, it should be noted that it is local in nature, and the percentage of supported innovations is minimal.

Methodological support for the development of schools and teachers is being implemented in all regions. But rather contradictory assessments of respondents representing different levels of the system of methodological work revealed its main drawbacks: insufficient volume of methodological support for the systematic development of schools; inconsistency, fragmentation, duplication; isolation of its individual directions and tasks solved at different levels of the general education system.

Assessing the changes necessary in the system of methodological work to improve the quality of general education, respondents believe that changes are required to a greater extent at the federal level of the system, and to a lesser extent at the regional level. 205 regional methodologists have the most pronounced attitudes to changes. According to Figure 6, almost a quarter of regional experts "voted" for major qualitative changes at the federal level, and only $17.1 \%$ and $15.6 \%$, respectively, at the municipal and institutional levels.

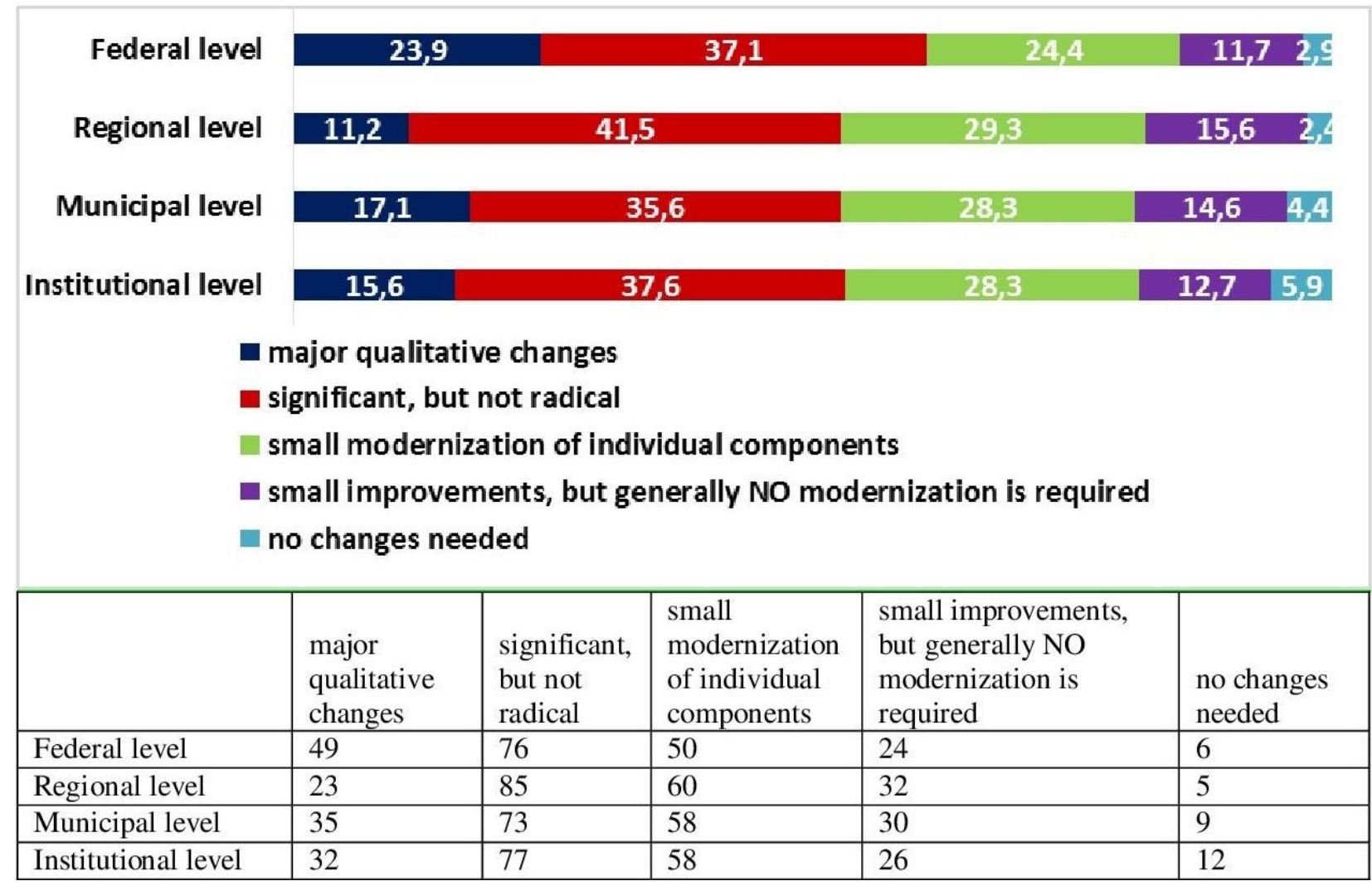

Fig. 6. Distribution of regional experts' opinions in assessing the changes needed in the system of methodological work to improve the quality of general education (\%)

The effect of changes in the system of methodological work will be maximal if they are aimed at solving the existing problems, eliminating the factors that reduce the quality and efficiency of methodological support of schools and teachers. Therefore, respondents were asked to assess the degree of the negative impact of individual factors on the results of methodological work in the region.

According to the overall rating obtained, the first place for the negative impact on the methodological activity belongs to the factor "lack or low quality of stimulation of methodological work". It means that in the system of methodological work there is no motivational environment, 
encouraging methodological professionals to do the most productive activities to improve the quality of education.

In second place is "insufficient quality of methodological support and instruction for both institutions of general education and teachers," which indicates a lack of consistency and insufficient quality of such support.

Third place is occupied by "inadequate organizational mechanisms of interaction between participants of methodological work "on the vertical axil" - a factor that plays a significant role in the development of a unified educational space, delivery of state policy in education, as well as in the distribution and coordination of efforts aimed at improving the quality of general education, at all levels of methodological work.

Regional and level differences in assessments of the significance of individual negative factors have been revealed. For example, as shown in Table 1, the assessments of respondents at the municipal and institutional levels, who ranked the factor "insufficient quality of methodological technologies" in third place, are more consistent, in contrast to regional methodological workers, who ranked "lack or low quality of development programs of methodological work in the region" in third place.

Table 1. Ratings of the factors negatively influencing the results of methodological work in the region

\begin{tabular}{|l|l|l|l|l|}
\hline $\begin{array}{l}\text { Factors that negatively affect the results of } \\
\text { methodological work in the region }\end{array}$ & \multicolumn{3}{|c|}{ Respondents } \\
\cline { 2 - 5 } Absence or low quality of incentives for methodological work & $\mathbf{R}$ & $\mathbf{1}$ & $\mathbf{1}$ & $\mathbf{1}$ \\
\hline $\begin{array}{l}\text { Insufficient quality of methodological support and instruction for } \\
\text { institutions of general education and teachers }\end{array}$ & 2 & 7 & 2 & 2 \\
\hline $\begin{array}{l}\text { Inadequate organizational mechanisms of interaction between } \\
\text { participants of methodological work "on the vertical axil" }\end{array}$ & 3 & 2 & 6 & 4 \\
\hline $\begin{array}{l}\text { The discrepancy between the proposed professional development } \\
\text { programs and the educational needs of teachers }\end{array}$ & 4 & 8 & 4 & 6 \\
\hline Insufficient quality of methodological work technologies & 5 & 5 & 3 & 3 \\
\hline $\begin{array}{l}\text { Lack or poor quality of development programs for methodological } \\
\text { work in the region }\end{array}$ & 6 & 3 & 7 & 5 \\
\hline $\begin{array}{l}\text { Inadequate organizational mechanisms for monitoring } \\
\text { methodological work and results evaluation }\end{array}$ & 7 & 4 & 8 & 8 \\
\hline $\begin{array}{l}\text { Inadequate distribution of functions among the subjects of } \\
\text { methodological work }\end{array}$ & 8 & 6 & 9 & 7 \\
\hline $\begin{array}{l}\text { Imperfection of the organizational mechanisms for cooperation } \\
\text { between participants of methodological work "horizontally" }\end{array}$ & 9 & 9 & 5 & 9 \\
\hline $\begin{array}{l}\text { RAP - rating of all survey participants } \\
\mathbf{R}-\text { rating of methodologists of the regional level } \\
\mathbf{M}-\text { rating of methodologists of the municipal level } \\
\text { I - rating of methodologists of the institutional level }\end{array}$ & & & \\
\hline
\end{tabular}

Of great importance for the development of methodological work systems in the regions is their innovative potential, modifiable by the ability to make purposeful changes in their components (goals, content, technologies, forms, means, conditions of methodological activity) and structure in accordance with objective needs and opportunities to improve the effectiveness and efficiency of methodological activities. In our study, the innovative potential of regional systems of methodological work was determined on the basis of assessments of changes that have occurred in them over the past 5-7 years.

According to the majority of respondents, there have been mainly "big" and "not big, but not small" changes in the regional systems of methodological work (Figure 7). The goals of methodological work, its content, methods and technologies, as well as methods of organization have changed to a greater extent. The assessment of methodological work and its conditions have undergone less change. 


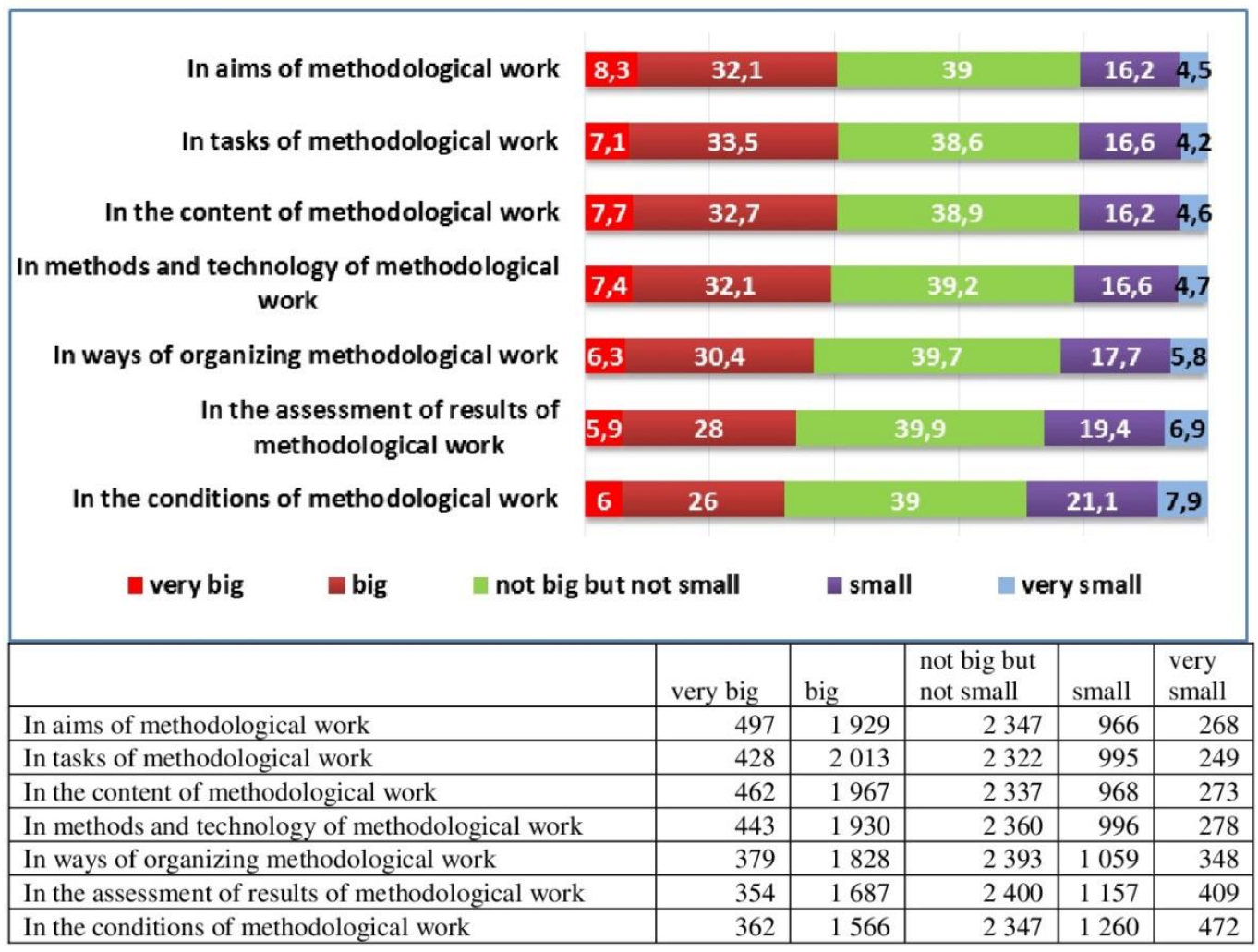

Fig. 7. Respondents' evaluation of the changes that have taken place in the components of the regional systems of methodological work over the past 5-7 years (\%)

Assessing the changes that are required in the system of methodological work to improve the quality of general education, the survey participants generally believe that the changes are more relevant at the federal level of the system, and least at the regional level (Figure 8).

\begin{tabular}{|c|c|c|c|c|c|}
\hline Federal level & \multicolumn{3}{|c|}{16,1} & 28,5 & $14,1 \quad 4,2$ \\
\hline Regional level & 11,5 & \multicolumn{2}{|c|}{37,3} & 33,7 & $13,9 \quad 3,6$ \\
\hline Municipal level & 14,6 & \multicolumn{2}{|c|}{32,7} & 33,4 & 15,2 \\
\hline \multirow[t]{3}{*}{ Institutional le } & 13 & \multicolumn{2}{|c|}{32,9} & 32 & 16,6 \\
\hline & \multicolumn{4}{|c|}{$\begin{array}{l}\text { @ major qualitative changes } \\
\text { @ significant, but not radical } \\
\text { Ismall modernization of individual components } \\
\text { @ small improvements, but generally NO modernization is required } \\
\text { = no changes needed }\end{array}$} & \\
\hline & $\begin{array}{l}\text { major } \\
\text { qualitative } \\
\text { changes }\end{array}$ & $\begin{array}{l}\text { significant, but } \\
\text { not radical }\end{array}$ & \begin{tabular}{|l} 
small \\
modernization \\
of individual \\
components \\
\end{tabular} & $\begin{array}{l}\text { small improvements, } \\
\text { but generally NO } \\
\text { modernization is } \\
\text { required }\end{array}$ & $\begin{array}{l}\text { no changes } \\
\text { needed }\end{array}$ \\
\hline Federal level & 970 & 2229 & 1709 & 845 & 254 \\
\hline Regional level & 689 & 2244 & 2020 & 836 & 218 \\
\hline Municipal level & 872 & 1967 & 2007 & 911 & 250 \\
\hline Institutional level & 778 & 1978 & 1921 & 997 & 333 \\
\hline
\end{tabular}

Fig. 8. Distribution of respondents' opinions in assessing changes, that are relevant in the system of methodological work to improve the quality of general education (\%) 
The refinement of the survey results obtained at different levels of management of the general education system and directions and tasks of methodological activity will provide for proper use of such results in the modernization of methodological work systems in general education.

\section{Conclusion}

As a result of the analysis of expert assessments of the system of methodological work in the Russian Federation, it was revealed:

- what is the degree of provision of methodological work with the necessary conditions (financial, informational, personnel, logistical, regulatory);

- what changes in the components of the methodological work system are necessary to improve the quality of general education;

- which models of the organization of the methodological service are the most promising at the present stage.

The results of the examination (for the entire sample, by levels and regions) allowed not only to see the overall picture of the methodological work and statistically determine its problem areas, but also to identify the reference points of its further development.

In our opinion, when building a new practice of methodological activity in general education, the use of the structural and functional model of methodological support for the systemic development of schools developed by us as a normative one will create the necessary prerequisites for improving the quality and international competitiveness of school education.

\section{Acknowledgements}

This work was done within the framework of the state assignment for the year 2020 to the Institute of Education Development Strategy of the Russian Academy of Education, project number 073-00007-20-01 "Development of a system of methodological work to provide a common educational space and improve the quality of general education in the Russian Federation".

\section{References}

Afanasyeva et al., 2016 - Afanasyeva, T.P., Yeliseyeva, I.A., Lazarev, V.S., Tyunnikov, Yu.S. (2016). A study of differences in the degree to which instructors are prepared to manage the development of the school they teach at. European Journal of Contemporary Education. 3(17): 272-283.

Afanasyeva et al., 2016a - Afanasyeva, T.P., Novikova, G.P. (2016) Modernizatsiya mekhanizmov innovatsionnoi deyatel'nosti doshkol'noi obrazovatel'noi organizatsii [Modernization of mechanisms of innovative activity of a preschool educational organization]. Yaroslavl' - Moskva: Izdatel'stvo «Kantsler». 388 p. [in Russian]

Afanasyeva, 2016 - Afanasyeva, T.P. (2016). Model' gotovnosti uchitelya k innovatsionnoy deyatel'nosti // Innovatsionnaya deyatel'nost' v obrazovanii [A model for instructor preparedness for innovation activity]. In G.P. Novikova, Innovation activity in education: Proceedings of the 10th International Research-to-Practice Conference. Yaroslavl'-Moskva: Izdatel'stvo «Kantsler», pp. 40-52. [in Russian]

Doklad ..., 2006 - Doklad «Innovatsionnoe razvitie obrazovaniya - osnova povysheniya konkurentosposobnosti Rossii». Zasedanie Gosudarstvennogo Soveta «O razvitii obrazovaniya v Rossiiskoi Federatsii» ot 24 marta 2006 g. [Report "Innovative development of education the basis for increasing the competitiveness of Russia". Meeting of the State Council "On the development of education in the Russian Federation" dated March 24, 2006]. [Electronic resource]. URL: http://https://www.rsr-online.ru/doc/2006-03-24/Gossovet.pdf (date of access: 23.09.2021). [in Russian]

Lazarev et al., 2008 - Lazarev, V.S. (2008). Upravlenie innovatsiyami v shkole [School innovation management]. Moskva: Tsentr pedagogicheskogo obrazovaniya. 352 p. [in Russian]

Lazarev, Razuvayeva, 2009 - Lazarev, V.S., Razuvayeva, T.N. (2009). Psikhologicheskaya gotovnost' pedagogicheskogo kollektiva $\mathrm{k}$ innovatsionnoy deyatel'nosti. [The psychological preparedness of a pedagogical team for innovation activity]. Surgut: RIO SurGPU. 195 p. [in Russian] 
Lazarev, Yeliseyeva, 2015 - Lazarev, V.S., Yeliseyeva, I.A. (2015). Issledovaniye pedagogicheskogo kollektiva kak sub"yekta innovatsionnoy deyatel'nosti [A study of a pedagogical team as the subject of innovation activity]. Voprosy Psikhologii. 1: 87-97. [in Russian]

Lazarev, 2010 - Lazarev, V.S. (2010). Model' i algoritm deyatel'nosti shkol v usloviyakh vvedeniya novykh FGOS obshchego obrazovaniya (nachal'naya stupen') [Model and algorithm of school activity in the context of the introduction of new federal state educational standards for general education (initial stage)]. Innovatsionnyye proyekty $i$ programmy $v$ obrazovanii. 3: 20-32. [in Russian]

Lazarev, 2011 - Lazarev, V.S. (2011). Innovatika v shkole: uchebnoye posobiye dlya sistemy vysshego pedagogicheskogo obrazovaniya i povysheniya kvalifikatsii rabotnikov obrazovaniya [Innovation at school: a textbook for the system of higher pedagogical education and advanced training of educational workers]. Surgut; Ekaterinburg: Gumanitarnyi un-t. 149 p. [in Russian]

Lazarev, 2015 - Lazarev, V.S. (2015). Nachala teorii razvivayushchikhsya pedagogicheskikh sistem [Principles of the theory of developing pedagogical systems]. Pedagogika. 6: 3-16. [in Russian]

Moiseev et al., 2013 - Moiseev, A.M., Moiseeva, O.M. (2013). Vneshnyaya podderzhka novshestv v obshcheobrazovatel'nykh organizatsiyakh [External support of innovations in general organizations]. Pedagogicheskoe obrazovanie i nauka. 5: 50-54. [in Russian]

O natsional'nykh..., 2020 - O natsional'nykh tselyakh razvitiya Rossiiskoi Federatsii na period do 2030 goda: Ukaz Prezidenta Rossiiskoi Federatsii ot 21 iyulya 2020 goda [On the national development goals of the Russian Federation for the period up to 2030: Decree of the President of the Russian Federation of July 21, 2020]. [Electronic resource]. URL: http://krem lin.revents/president/news/63728 (date of access: 11.11.2021). [in Russian]

Tyunnikov, 2017 - Tyunnikov, Y.S. (2017). Classification of Innovation Objectives set for Continuing rofessional Teacher Development. European Journal of Contemporary Education. 6(2): 167-181.

Zagrivnaya, 2006 - Zagrivnaya, T.A. (2006). Stanovlenie nauchno-metodicheskoi kompetentnosti pedagogov $\mathrm{v}$ protsesse professional'noi deyatel'nosti [Formation of scientific and methodological competence of teachers in the process of professional]: dis. ... kand. ped. nauk: 13.00.01. Sankt-Peterburg. 256 p. [in Russian] 